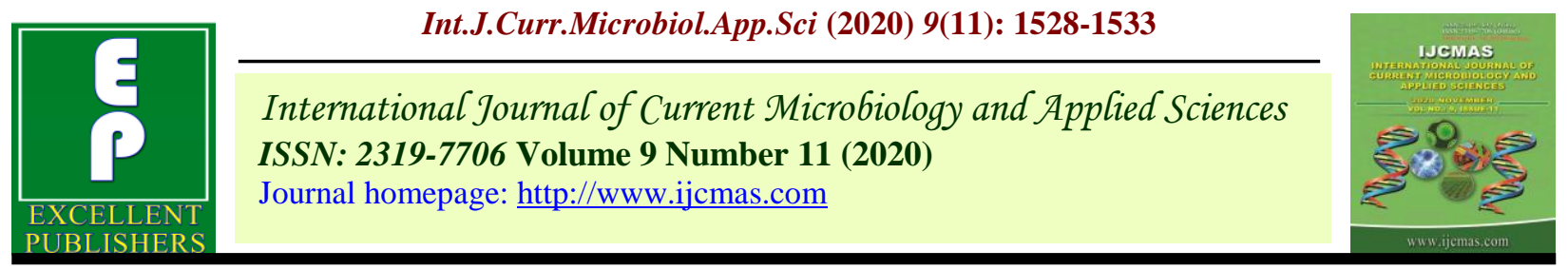

\title{
Effect of Irrigation and Nitrogen Levels on Nitrogen Content, Uptake and Water Productivity of Clusterbean (Cyamopsis tetragonoloba) in IGNP Stage-II
}

\author{
Rameshwr Lal Mandeewal $^{1^{*}}$, M. L. Soni ${ }^{2}$, I. J. Gulati ${ }^{3}$, Hansraj Shivran ${ }^{3}$, \\ Raj Kumar ${ }^{1}$ and Ramesh Choudhary ${ }^{3}$
}

${ }^{1}$ ICAR-Central Sheep and Wool Research Institute, ${ }^{3}$ Swami Keshwanand Rajasthan Agricultural University, Avikanagar Rajasthan, India

${ }^{2}$ ICAR-Central Arid Zone Research Institute, RRS, Bikaner Rajasthan, India

*Corresponding author

\section{A B S T R A C T}

Keywords

Clusterbean, Irrigation, Nitrogen, Yield, Water productivity

Article Info

Accepted:

12 October 2020

Available Online:

10 November 2020
An experiment was carried out at village Bajju, Bikaner, Rajasthan during kharif season of 2016 to Effect of Irrigation and Nitrogen Levels on Nitrogen Content, Uptake and Water Productivity of Clusterbean (Cymopsis tetragonoloba) in IGNP Stage-II. The treatment comprising three levels of irrigation $(100,200$ and $300 \mathrm{~mm})$ and four levels of nitrogen $(0$, 20,40 and $60 \mathrm{~kg} \mathrm{~N} \mathrm{ha}^{-1}$ ) comprising a total of twelve treatment combinations in split plot design with four replications. Increasing level of irrigation from $100 \mathrm{~mm}$ to $200 \mathrm{~mm}$ increased the yield and nitrogen uptake by seed, stover and total plant, water productivity and protein yield of clusterbean over $100 \mathrm{~mm}$ and remained at par with $300 \mathrm{~mm}$. Application of $40 \mathrm{~kg} \mathrm{~N} \mathrm{ha}^{-1}$ produced significantly highest yield, nitrogen content in seed and stover, nitrogen uptake by seed, stover and total plant, protein content in seed and protein yield of clusterbean over control and $20 \mathrm{~kg} \mathrm{~N}^{-1}$ but it remained at par with $60 \mathrm{~kg}$ $\mathrm{N} \mathrm{ha}{ }^{-1}$. Interaction effect of irrigation and nitrogen was also found significant for yield, nitrogen uptake and protein yield of clusterbean and highest values of these parameters were recorded with $200 \mathrm{~mm}$ irrigation in combination with $40 \mathrm{~kg} \mathrm{~N} \mathrm{ha}^{-1}$.

\section{Introduction}

Rajasthan is predominantly a rainfed state with precipitation being major source of annual renewable water supply. With the rapidly increasing population and rising standards of living as well as exponential growth of industrialization, the water availability in the state is decreasing at an alarming rate, and water scarcity is growing rapidly. Scarcity of water resources and growing competition for water in many sectors reduce its availability for irrigation. Effective management of water for crop production in water scarce areas requires efficient approaches for improving water productivity. These include effective management practices, growing high value water efficient crops and cropping systems. The crops grown in IGNP stage II are high 
water requiring and farmers use excess irrigation for growing the crops. Therefore, technological interventions are required to improve crop water productivity of the area. Groundnut and cluster bean are the major kharif season crops of IGNP stage II. These crops not only play a great role in economic growth of the farmers of this region, but also contribute a lot in India's economy. India accounts about 80 per cent of the world clusterbean production. Total area under the crop in India was around 59.62 lakh hectares with an annual production of 35.87 lakh tones (Mukesh et al., 2018). About 85 per cent of total clusterbean production is contributed by Rajasthan and Haryana states, only. In Rajasthan, total area under clusterbean was 46.30 lakh ha production was 27.47 lakh tones contributing 70 per cent of total clusterbean (Mukesh et al., 2018). Nitrogen is such a star nutrient in crop production that it can never be ignored. Among all nutrients, crop demand for $\mathrm{N}$ is greatest. All plants need $\mathrm{N}$ to grow, develop leaves and branches, carry out photosynthesis and produce proteins which are compounds of nitrogen. Moreover, the level of nitrogen fertilization and irrigation is very important to increase the fertilizer efficiency, decrease the loss of water and improve water productivity without compromising the crop yield. Hence, looking to the above facts, an experiment entitled "Evaluation of the CropSyst Model to Simulate the Effect of Irrigation and Nitrogen Levels on Yield of Groundnut and Clusterbean in IGNP Stage II" was under taken.

\section{Materials and Methods}

An experiment was carried out during kharif season of 2016 at village Bajju, (072 47'79'E longitude and $28^{\circ} 14^{\prime} 23^{\prime \prime} \mathrm{N}$ latitude and 234.7 $\mathrm{m}$ above mean sea) Bikaner, Rajasthan, India. The field experiment was laid out in kharif season 2016 with three levels of irrigation i.e.
100, 200 and $300 \mathrm{~mm}$ and four levels of nitrogen i.e. $0,20,40$ and $60 \mathrm{~kg} \mathrm{~N}^{-1}$ in split plot design with four replications. Urea was used as the source of nitrogen. Half dose of nitrogen was applied as a basal dose through urea prior to sowing. The remaining half dose of nitrogen was top dressed through urea at first irrigation. As per National Agricultural Research Project (NARP), Bikaner falls in Agro-climatic zone IC (Hyper Arid Partially Irrigated North Western Plain Zone). According to National Planning Commission, Bikaner falls under Agro-climatic zone XIV (Western Dry Region) of India. The climate of this zone is typically arid characterized by aridity of the atmosphere and slight salinity in the rhizosphere with extremes of temperature both in summers and winters. Clusterbean crop received $131 \mathrm{~mm}$ of rainfall in the growing season. The soils of the area are loamy sand in texture and slightly alkaline in reaction $(\mathrm{pH} 8.1)$ with low in organic matter ( 0.13 per cent), low in available nitrogen $\left(114.5 \mathrm{~kg} \mathrm{ha}^{-1}\right)$, medium in available phosphorus (15.9 $\mathrm{kg} \mathrm{ha}^{-1}$ ) and potassium (189.2 $\left.\mathrm{kg} \mathrm{ha}^{-1}\right)$.

\section{Results and Discussion}

\section{Irrigation levels}

The experimental findings presented in table 1 indicated that successive increase in irrigation level up to $200 \mathrm{~mm}$ significantly increased the seed yield and stover yield of clusterbean over $100 \mathrm{~mm}$ irrigation but remained at par with $300 \mathrm{~mm}$ irrigation level. The per cent increase in seed and stover yield due to application of $200 \mathrm{~mm}$ irrigation was of the order of 33.2 per cent in seed and 26.6 per cent in stover over $100 \mathrm{~mm}$ irrigation. The main reason behind significantly higher seed and stover yield of clusterbean due to irrigation level of $200 \mathrm{~mm}$ might be adequate availability of irrigation water and plant nutrients with frequent and optimum number 
of irrigations applied might have resulted in higher yields. Similar results were also reported by Sharma and Verma (2010). Stimulated vegetative growth of clusterbean on account of frequent supply of water maintained adequate available soil moisture in the root zone throughout the crop-growth period which, in turns, got reflected in increased leaf area, dry matter and higher seed and straw yield. These findings are in accordance with the findings of Saren et al., (2004). The data clearly showed that increasing level of irrigation from $100 \mathrm{~mm}$ to $200 \mathrm{~mm}$ also increased the nitrogen uptake by seed, stover and total plant but remained at par with $300 \mathrm{~mm}$. The improvement in nitrogen uptake by seed, stover and total plant due to $200 \mathrm{~mm}$ irrigation was 35.7 per cent by seed, 33.7 per cent by stover and 35.1 per cent by total plant over $100 \mathrm{~mm}$ irrigation. Increase in level of irrigation significantly increased nitrogen uptake by seed, stover and total plant over lower level but it could not bring significant effect as compared to highest level. Availability of nitrogen would be high at optimum levels of available soil moisture. Since the nutrient uptake is a function of its content in crop plant and seed and stover yield of the crop. The increase in nitrogen uptake by the crop could be ascribed to the cumulative effect of enhanced seed and stover yield. The increased nitrogen uptake in crop could be ascribed to more availability of moisture in rhizosphere which resulted in better root proliferation and might have improved availability of nutrients particularly nitrogen. Similar results were also observed by Pessarakli et al., (2005). The data apparently showed that the water productivity in terms of ET increased significantly with the increase in the levels of irrigation. Significantly highest water productivity in terms of ET was recorded with $200 \mathrm{~mm}$ level of irrigation which was higher by 32.4 per cent over $100 \mathrm{~mm}$ level of irrigation (Table 2 and 3).

Table.1 Effect of irrigation and nitrogen levels on yield, nitrogen content and nitrogen uptake of clusterbean

\begin{tabular}{|c|c|c|c|c|c|c|c|}
\hline \multirow[t]{2}{*}{ Treatments } & \multicolumn{2}{|c|}{ Yield $\left(\mathrm{kg} \mathrm{ha}^{-1}\right)$} & \multicolumn{2}{|c|}{$\mathrm{N}$ content (per cent) } & \multicolumn{3}{|c|}{$\mathrm{N}$ uptake $\left(\mathrm{kg} \mathrm{ha}^{-1}\right)$} \\
\hline & Seed & Stover & Seed & Stover & Seed & Stover & Total plant \\
\hline \multicolumn{8}{|c|}{ Irrigation levels (mm) } \\
\hline 100 & 714 & 1942 & 2.90 & 0.53 & 20.75 & 10.29 & 31.04 \\
\hline 200 & 951 & 2458 & 2.92 & 0.55 & 28.15 & 13.76 & 41.92 \\
\hline 300 & 1018 & 2649 & 2.92 & 0.54 & 30.14 & 14.72 & 44.87 \\
\hline $\mathrm{SEm} \pm$ & 32 & 74 & 0.05 & 0.02 & 1.31 & 0.86 & 2.09 \\
\hline $\mathrm{CD}(\mathrm{P}=0.05)$ & 111 & 255 & NS & NS & 4.52 & 2.98 & 7.24 \\
\hline \multicolumn{8}{|c|}{ Nitrogen levels $\left(\mathrm{kg} \mathrm{ha}^{-1}\right)$} \\
\hline 0 & 676 & 1877 & 2.66 & 0.45 & 17.98 & 8.38 & 26.37 \\
\hline 20 & 873 & 2257 & 2.87 & 0.53 & 24.99 & 11.85 & 36.84 \\
\hline 40 & 996 & 2576 & 3.06 & 0.59 & 30.62 & 15.17 & 45.79 \\
\hline 60 & 1031 & 2689 & 3.07 & 0.60 & 31.81 & 16.29 & 48.09 \\
\hline $\mathrm{SEm} \pm$ & 26 & 79 & 0.06 & 0.02 & 1.02 & 0.66 & 1.63 \\
\hline $\mathrm{CD}(\mathrm{P}=0.05)$ & 74 & 230 & 0.18 & 0.04 & 2.95 & 1.91 & 4.72 \\
\hline
\end{tabular}


Table.2 Effect of irrigation and nitrogen levels on water productivity, protein content and protein yield of clusterbean

\begin{tabular}{|c|c|c|c|}
\hline Treatments & $\begin{array}{l}\text { Water productivity }\left(\mathrm{kg} \mathrm{m}^{-3}\right) \\
\text { in terms of ET }\end{array}$ & $\begin{array}{l}\text { Protein content } \\
\quad \text { (per cent) }\end{array}$ & $\begin{array}{l}\text { Protein yield } \\
\left(\mathrm{kg} \mathrm{ha}^{-1}\right)\end{array}$ \\
\hline \multicolumn{4}{|c|}{ Irrigation levels (mm) } \\
\hline 100 & 0.34 & 18.14 & 129.70 \\
\hline 200 & 0.45 & 18.25 & 175.96 \\
\hline 300 & 0.49 & 18.25 & 188.40 \\
\hline $\mathrm{SEm}+$ & 0.015 & 0.34 & 8.16 \\
\hline $\mathrm{CD}(\mathrm{P}=0.05)$ & 0.053 & NS & 28.25 \\
\hline \multicolumn{4}{|c|}{ Nitrogen levels $\left(\mathrm{kg} \mathrm{ha}^{-1}\right)$} \\
\hline 0 & 0.33 & 16.64 & 112.39 \\
\hline 20 & 0.42 & 17.91 & 156.21 \\
\hline 40 & 0.48 & 19.10 & 191.37 \\
\hline 60 & 0.50 & 19.21 & 198.79 \\
\hline SEm+ & 0.012 & 0.40 & 6.36 \\
\hline $\mathrm{CD}(\mathrm{P}=0.05)$ & 0.036 & 1.15 & 18.45 \\
\hline
\end{tabular}

Table.3 Interaction effect of irrigation and nitrogen levels on seed and stover yield, nitrogen uptake and protein yield of clusterbean

\begin{tabular}{|c|c|c|c|c|c|c|c|}
\hline \multirow[t]{2}{*}{ Treatments } & \multicolumn{2}{|c|}{ Yield $\left(\mathrm{Kg} \mathrm{ha}^{-1}\right)$} & \multicolumn{3}{|c|}{ N uptake (kg ha $\left.{ }^{-1}\right)$} & \multirow{2}{*}{$\begin{array}{c}\text { Water } \\
\text { productivity (kg m } \\
{ }_{3}^{3} \text { ) in terms of ET }\end{array}$} & \multirow{2}{*}{$\begin{array}{c}\text { Protein } \\
\text { yield }(\mathbf{k g} \\
\left.\text { ha }^{-1}\right)\end{array}$} \\
\hline & Seed & Stover & Seed & Stover & $\begin{array}{l}\text { Total } \\
\text { plant }\end{array}$ & & \\
\hline I1N1 & 594 & 1921 & 16.43 & 8.66 & 25.09 & 0.29 & 102.7 \\
\hline I1N2 & 725 & 1874 & 21.05 & 9.99 & 31.04 & 0.35 & 131.6 \\
\hline I1N3 & 758 & 1961 & 22.51 & 11.08 & 33.59 & 0.37 & 140.7 \\
\hline I1N4 & 778 & 2012 & 23.02 & 11.42 & 34.44 & 0.38 & 143.9 \\
\hline I2N1 & 696 & 1800 & 18.30 & 8.17 & 26.47 & 0.34 & 114.4 \\
\hline I2N2 & 878 & 2271 & 24.58 & 11.72 & 36.30 & 0.42 & 153.6 \\
\hline I2N3 & 1079 & 2789 & 33.52 & 16.81 & 50.33 & 0.52 & 209.5 \\
\hline I2N4 & 1150 & 2974 & 36.23 & 18.34 & 54.56 & 0.56 & 226.4 \\
\hline I3N1 & 738 & 1909 & 19.22 & 8.33 & 27.54 & 0.36 & 120.1 \\
\hline I3N2 & 1016 & 2626 & 29.35 & 13.83 & 43.18 & 0.49 & 183.5 \\
\hline I3N3 & 1152 & 2978 & 35.83 & 17.62 & 53.45 & 0.56 & 223.9 \\
\hline I3N4 & 1165 & 3082 & 36.17 & 19.11 & 55.28 & 0.56 & 226.1 \\
\hline SEm+ & 44 & 137 & 1.76 & 1.14 & 2.82 & 0.021 & 11.01 \\
\hline $\mathrm{CD}(\mathrm{P}=\mathbf{0 . 0 5})$ & 129 & 399 & 5.11 & 3.31 & 8.18 & 0.062 & 31.95 \\
\hline
\end{tabular}

The data further showed that increasing level of irrigation from $100 \mathrm{~mm}$ to $200 \mathrm{~mm}$ increased the protein yield but found at par with $300 \mathrm{~mm}$. Protein yield is a function of protein content in seed and seed yield of the crop and main reason of improvement in protein yield was improvement in seed yield of clusterbean. These findings are in 
accordance with the findings of Saren et al., (2004). While, it is evident from the data that nitrogen content in seed and stover was not influenced due to different levels of irrigation.

\section{Nitrogen levels}

The experimental findings indicated that increase in level of nitrogen up to $40 \mathrm{~kg}$ $\mathrm{N}$ ha ${ }^{-1}$ significantly increased the seed yield and stover yield of clusterbean. Beyond this level, seed yield did not increase significantly any further. Application of $40 \mathrm{~kg} \mathrm{~N} \mathrm{ha}{ }^{-1}$ increased the seed yield by 47.3 and 14.1 per cent and stover yield by 37.2 and 14.1 per cent over control and $20 \mathrm{~kg} \mathrm{~N} \mathrm{ha}{ }^{-1}$, respectively. Since yield is the resultant of additive and complementary effect of plant growth and yield attributing parameters and the yield attributing characters had better expression at $40 \mathrm{~kg} \mathrm{~N}^{-1}$ which ultimately led towards an increase in seed and stover yields. Under the higher supply of nitrogen, crops synthesized more photosynthates and the storage organ was better developed. Yield can be considered as the final expression of the physiological and metabolic activities of plants and is governed by various factors. These yield-attributing factors have direct bearing on plant productivity and for increasing the yield. Nitrogen is closely linked to control the vegetative growth of plant and hence determines the fate of reproductive cycle (Wojnowska et al., 1995). The increases in seed yield as a result of nitrogen application have also been reported by many research workers viz. Patel et al., (2005), Rathore et al., (2007) and Muhammad et al., (2010).

It is apparent from the data that nitrogen content in seed and stover, nitrogen uptake by seed, stover and total plant, protein content and protein yield of clusterbean significantly increased with application of nitrogen up to $40 \mathrm{~kg} \mathrm{~N} \mathrm{ha}{ }^{-1}$ over control and $20 \mathrm{~kg} \mathrm{~N} \mathrm{ha}^{-1}$, beyond this level it did not increase significantly any further. The positive influence of nitrogen fertilization on nitrogen content in seed and stover appears to be due to improved nutritional environment in the crop root zone and plant system. Such improvement in the nutritional environment of the root zone might have helped in development of better root system leading to absorption of more and more nutrients from soil compared with control. Increased availability of nitrogen in the root zone stimulated the its uptake by crops, which translocated to various plant parts due to increased metabolic activities at cellular level. Since nutrient uptake is a function of nutrient content of plant parts and total dry matter of the crop in terms of pod and haulm yields, application of nitrogen up to $40 \mathrm{~kg} \mathrm{ha}^{-1}$ increased the uptake of $\mathrm{N}$ significantly. Significant improvement in nutrient contents and/or their uptake due to nitrogen application (upto $50 \mathrm{~kg} \mathrm{~N} \mathrm{ha}^{-1}$ ) were observed by Patel et al., (1995), Chawale et al., (1995) and Deka et al., (2001). Protein content is directly related to nitrogen content and increases with increase in $\mathrm{N}$ content in seed. Protein yield is a function of protein content in seed and seed yield of the crop and main reason of improvement in protein yield was improvement in seed yield of clusterbean. It is evident from the data that increasing levels of nitrogen significantly increased water productivity in terms of ET. Further data revealed that application of $40 \mathrm{~kg} \mathrm{~N} \mathrm{ha}{ }^{-1}$ significantly improved water productivity in terms of ET over control and $20 \mathrm{~kg} \mathrm{~N} \mathrm{ha}^{-1}$ but it remained at par with $60 \mathrm{~kg} \mathrm{~N} \mathrm{ha}^{-1}$.

\section{Interaction effect of irrigation and nitrogen levels}

Data clearly showed that interaction effect of irrigation and nitrogen on seed yield, stover yield, nitrogen uptake by seed, stover and total plant and protein yield of clusterbean 
was found significant. At all the levels of nitrogen application, increase in level of irrigation increased the seed yield from 100 $\mathrm{mm}$ to $200 \mathrm{~mm}$, beyond this level increase in all these parameters was non-significant. Similarly, at all the levels of irrigation, increase in levels of nitrogen up to $40 \mathrm{~kg} \mathrm{~N}$ $\mathrm{ha}^{-1}$ increased all these parameters which remained statistically at par with $60 \mathrm{~kg} \mathrm{~N} \mathrm{ha}^{-1}$.

\section{References}

Chawale VV, Bharad GM, Kohale SK and Nagdeve MB. 1995. Effect of nitrogen and FYM on yield, quality and nitrogen uptake on summer groundnut under micro sprinkler irrigation. $P \quad K \quad U$ Research Journal 19(2): 171-172.

Deka NC, Dutta R and Gogoi PK. 2001. Effect of lime and nitrogen on nutrient uptake and residual soil fertility in groundnut. Legume Research 24(2): 118120.

Muhammad A, Muhamma T, Muhammad NA, Muhammad N, Zubair A, Muhammad T and Ibrahim M. 2010. Effect of nitrogen applications on growth, forage yield and quality of three clusterbean varieties. Pakistan Journal of Life and Social Science, 8(2): 111116.

Mukesh J, Sharma H and Meera 2018. An economic analysis of cluster bean in Bikaner district of Rajasthan, International Journal of Agriculture Sciences, 10 (7) 5672-5675.

Patel GM, Solanki NP and Patel RS. 1995. Effect of seed rate and N P fertilizers on the quality and economics of summer groundnut (Arachis hypogaea L.) Gujarat Agricultural University Research Journal, 20(2): 154-156.

Patel IC, Patel MM, Patel AG and Tikka SBS. 2005. Response of kharif guar to fertilizers and row spacing under rainfed conditions. Indian Journal Pulses Research, 18(2): 246-247.

Pessarakli MM, Morgan PV and Gilbert JJ. 2005. Dry matter yield, protein synthesis, starch and fibre content of barley and wheat plants under two irrigation regimes. Journal Plant Nutrition, 28(7): 1,227-1,241.

Rathore VS, Singh JP, Soni ML and Beniwal RK. 2007. Effect of nutrient management on growth, productivity and nutrient uptake of rainfed cluster bean (Cyamopsis tetragonoloba) in arid region. Indian Journal of Agricultural Sciences, 77(6): 349-353.

Saren BK, Dey S and Mandal D. 2004. Effect of irrigation and sulphur on yield attributes productivity, consumptive use and consumptive use efficiency of wheat (Triticum aestivum L). Indian Journal of Agricultural Sciences, 74: 257-261.

Sharma RK and Verma RPS. 2010. Effect of irrigation, nitrogen and varieties on the productivity and grain making quality in barley. Cereal Research Communications, 38(3): 419-428.

Wojnowska T, Panak $\mathrm{H}$ and Siekiewiez S. 1995. Reaction of winter oil-seed rape to increasing level of nitrogen fertilizer application under condition of Ketrzynchernozem. Rosling Oleiste, 16: 173-180.

\section{How to cite this article:}

Rameshwr Lal Mandeewal, M. L. Soni, I. J. Gulati, Hansraj Shivran, Raj Kumar and Ramesh Choudhary. 2020. Effect of Irrigation and Nitrogen Levels on Nitrogen Content, Uptake and Water Productivity of Clusterbean (Cyamopsis tetragonoloba) in IGNP Stage-II. Int.J.Curr.Microbiol.App.Sci. 9(11): 1528-1533. doi: https://doi.org/10.20546/ijcmas.2020.911.181 